\title{
Amphibians and larvae of aquatic insects as new paratenic hosts of Anguillicola crassus (Nematoda: Dracunculoidea), a swimbladder parasite of eels
}

\author{
F. Moravec*, B. Škoríková
}

Institute of Parasitology, Academy of Sciences of the Czech Republic, Branišovská 31, 37005 České Budĕjovice, Czech Republic

\begin{abstract}
Amphibians (tadpoles of the frog Bombina bombina [L.) and the newt Triturus vulgaris [L.J) and aquatic insects (larvae of the alderfly Sialis lutaria [L.] [Megaloptera], dragonflies Sympetrum sanguineum [Müller] and Coenagrion puella [L.] /Odonata], and the caddisfly Oligotrichia striati [L.] [Trichoptera]) were found to serve as paratenic hosts for the third-stage larvae $\left(L_{3}\right)$ of the nematode Anguillicola crassus Kuwahara, Niimi et Itagaki, 1974, a pathogenic swimbladder parasite of the eel Anguilla anguilla (L.) in Europe and elsewhere. This is the first eviclence that, in addition to prey fishes and some aquatic snails, amphibians and aquatic insects can serve as paratenic hosts for this nematode parasite. A. crassus third-stage larvae were found, largely unencapsulated (encapsulated only in $S$. lutaria), mostly in the body cavity, on the gut surface and, less often, in the liver and in the subcutaneous tissue of legs in amphibians, and in the body cavity and on the gut surface in insect larvae; they could survive for at least $49 \mathrm{~d}$ in $T$ vulgaris and $69 \mathrm{~d}$ in $S$. lutaria. The capability of these larvae from S. Iutaria ( $69 \mathrm{~d}$ post-infection) to infect the definitive host (eel) was confirmed by experimental infection of an eel.
\end{abstract}

KEY WORDS: Parasitic nematode Anguillicola crassus. Paratenic host Bombina bombina . Triturus vulgaris A Aquatic insects Sialis lutaria Coenagrion puella Sympetrum sanguineum - Oligotrichia striati

\section{INTRODUCTION}

The nematode Anguillicola crassus Kuwahara, Niimi et Itagaki, 1974 is a pathogenic swimbladder parasite of eels, now distributed in East Asia, Europe, North Africa and North America (southern USA); in addition to being reported in the European eel Anguilla anguilla (L.), it is reported from Anguilla japonica Temminck et Schlegel and Anguilla rostrata (LeSueur) (Kuwahara et al. 1974, Moravec \& Taraschewski 1988, Johnson et al. 1995, Fries et al. 1996). Since this parasite is known to be the cause of serious problems not only in farmed eels but also in wild eel populations (e.g. van Banning \& Haenen 1990, Molnár et al. 1991, Baruš 1994, 1995, Ooi \& Wang 1996), the question of the role of paratenic hosts for the transmission of this nematode may be of practical importance, because paratenic hosts are

·E-mail: moravec@paru.cas.cz probably the principal source of $A$. crassus infection for eels under natural water conditions.

The development of Anguillicola crassus involves an obligate intermediate host, different species of copepods and ostracods, in which the nematode larvae reach the third stage, a stage that is infective to the definitive host (eel) (De Charleroy et al. 1990, Petter et al. 1990, Moravec et al. 1993, Moravec \& Konecny 1994). Although the infected intermediate hosts, which are ingested by the definitive host (eel), are currently the source of $A$. crassus infection, various species of fish were found to serve as paratenic hosts in which the nematode larvae remain alive and keep their capability to infect eels (Petter et al. 1989, De Charleroy et al. 1990, Haenen \& van Banning 1990, Thomas \& Ollevier 1992, Moravec \& Konecny 1994, Pazooki \& Székely 1994, Reimer et al. 1994, Székely 1994, 1995). Recently Moravec (1996) demonstrated experimentally that not only prey fishes, but also aquatic snails, may become paratenic hosts of $A$. crassus. 
The present study explores further the possible role of paratenic hosts in the life cycle of Anguillicola crassus.

\section{MATERIALS AND METHODS}

Gravid females of Anguillicola crassus with eggs containing motile second-stage larvae were recovered from the swimbladder of eels Anguilla anguilla (L.) caught in the water reservoir of the Orlik Dam on the Vltava River near the village of Štédronín, central Bohemia, Czech Republic, in May and October 1996 and June and October 1997. The live nematodes taken from the host's body were placed in small petri dishes containing physiological saline, where, using the dissecting microscope, their uteri, which contained eggs with fully developed larvae, were removed with the aid of fine mounting needles; it was necessary to work with caution to avoid a rupture of the nematode's intestine, which is full of the host's blood, which might have complicated the work. The separated uteri were transferred to other small petri dishes with physiological saline, where the nematode eggs were teased from them with mounting needles.

Feeding experiments with copepod intermediate hosts were carried out in large petri dishes $120 \mathrm{~cm}$ in diameter) filled with water. Each dish contained a few hundred (usually about 300) copepods, to which about 1000 parasite eggs with fully developed larvae were added. Cyclops strenuus Fischer, Macrocyclops albidus (Jurine) and Macrocyclops fuscus (Jurine) originating from a few ponds near České Budějovice, South Bohemia, were used as experimental intermediate hosts. These were kept at the laboratory temperature of 20 to $22^{\circ} \mathrm{C}$. They were fed with Paramecium; a few specimens were examined at short intervals (several days) until the nematode larvae attained their third stage within these hosts. Then the infected copepods were used for subsequent feeding experiments with possible paratenic hosts.

Tadpoles of the frog Bombina bombina (L.) (Discoglossidae, Anura) and those of the newt Triturus vulgaris (L.) (Salamandridae, Caudata), as well as aquatic isopods Asellus aquaticus L., larvae of dragonflies Sympetrum sanguineum (Müller) (Libellulidae, Odonata), Coenagrion puella (L.), Lestes sponsa Hansemann and Sympecma fusca Linden (all Lestidae, Odonata) and the caddisfly Oligotrichia striati (L.) (Phryganeidae, Trichoptera) were collected from swamps and pools near České Budějovice, and larvae of the alderfly Sialis lutaria (L.) were collected from a small brook in the woods at Dobrá Voda near České Budéjovice. These tadpoles were placed in small glass aquaria (1 l) and aquatic insect larvae in large petri dishes (20 cm in diameter) to which an indeterminable number (about several hundred to each vessel) of copepods harbouring Anguillicola crassus third-stage larvae was added; prior to this, infected copepods had been concentrated by pouring out the water with copepods from several petri dishes in which they had originally been infected through a fine net. All these experimental animals were kept at the laboratory temperature of 20 to $22^{\circ} \mathrm{C}$; after copepods had disappeared from the experimental vessels, the insect larvae were fed with chironomid larvae until they were microscopically examined for the presence of $A$. crassus larvae at different intervals.

The eels Anguilla anguilla (L.) (total body lengths 17 and $20 \mathrm{~cm}$ ) used in one experiment were originally obtained as elvers from Italy and then kept at a low temperature $\left(10^{\circ} \mathrm{C}\right)$ in the laboratory in Ceské Budějovice for approximately $3 \mathrm{yr}$. They were fed during this period with tubificids. Ten control eels had previously been examined and found to be parasite free. The experimental eels were kept at the laboratory temperature of 20 to $22^{\circ} \mathrm{C}$ and were fed with tubificids until they were examined on Day 27 possible infection (PI).

\section{RESULTS}

\section{Expt 1}

Copepods Cyclops strenuus were infected with $A n$ guillicola crassus in 10 large petri dishes in mid-May 1996. An examination of a few copepods $16 \mathrm{~d}$ PI showed that approximately half of them harboured 1 to 3 A. crassus infective third-stage larvae $\left(\mathrm{L}_{3}\right)$; however, only a small number of copepods survived These were added to a small aquarium (2 l) with 13 larger tadpoles of Bombina bombina, 1 large tadpole of Triturus vulgaris, and 1 larva of the dragonfly Sympetrum sanguineum. B. bombina tadpoles examined $5 \mathrm{~d}$ PI harboured 1 to 2 free, vigorously moving A. crassus larvae $\left(\mathrm{L}_{3}\right)$ in their body cavity. On Day 12, 2 B. bombina tadpoles were examined, harbouring 3 and 14 unencapsulated $A$. crassus larvae $\left(\mathrm{L}_{3}\right)$ (body length 952 to $1074 \mu \mathrm{m}$ long and maximum width 40 to $43 \mu \mathrm{m}$ ); one of the more heavily infected tadpoles had 11 larvae in the liver and 3 in the body cavity, whereas another one had larvae only in the body cavity.

Meanwhile, 3 Bombina bombina tadpoles metamorphosed to small frogs (body size about $3 \mathrm{~cm}$ ) which died on Days 14, 16 and 19 PI. The first frog (14 d PI) contained altogether 5 Anguillicola crassus larvae $\left(\mathrm{L}_{3}\right)$, 2 in the liver and 3 in the body cavity, and the second one (16 d PI) 1 A. crassus larva $\left(\mathrm{L}_{3}\right)$ in the subcutaneous tissue; no larvae were found in the third frog. The last 
$2 B$. bombina tadpoles (size about $2 \mathrm{~cm}$ ) were examined 29 and $33 \mathrm{~d}$ PI, and they were found to contain 1 and 3 live, unencapsulated $A$. crassus larvae $\left(\mathrm{L}_{3}\right)$, respectively, measuring 898 to $911 \mu \mathrm{m}$ in length and $34 \mu \mathrm{m}$ in maximum width.

The Triturus vulgaris tadpole (size $2 \mathrm{~cm}$ ) and Sympetrum sanguineum larva, examined on Day 33 IP, proved to be uninfected.

\section{Expt 2}

Copepods Cyclops strenuus were infected with Anguillicola crassus in 10 large petri dishes in midOctober 1996. On Day 15 PI, all surviving copepods, some of them already containing nematode thirdstage larvae, were concentrated and added to a $500 \mathrm{ml}$ glass vessel with a few aquatic insect larvae (Sympetrum sanguineum and unidentified mayfly nymphs). Two surviving $S$. sanguineum were examined $8 \mathrm{~d}$ after possible infection; one of them harboured $3 \mathrm{~A}$. crassus larvae $\left(\mathrm{L}_{3}\right)$ in the body cavity, whereas the second one as well as all mayflies proved to be free of parasites.

\section{Expt 3}

Copepods (Cyclops strenuus, Megacyclops albidus, Megacyclops fuscus) were infected with Anguillicola crassus in 19 large petri dishes in mid-June 1997. On Day $12 \mathrm{PI}, 6 \mathrm{M}$. albidus and $M$. fuscus were examined and half of them proved to harbour 2 to $5 \mathrm{~A}$. crassus $\mathrm{L}_{3}$. On the following day ( $13 \mathrm{~d} \mathrm{PI}$ ), the surviving copepods were concentrated; one-half of them was added to a 31 aquarium with about 15 dragonfly larvae (Coenagrion puella, Lestes sponsa, Sympecma fusca, Sympetrum sanguineum), and the second half to a small $(500 \mathrm{ml})$ glass vessel with 3 Triturus vulgaris tadpoles (body size about $2 \mathrm{~cm}$ ) and 1 Bombina bombina tadpole (about $1 \mathrm{~cm}$ ). All dragonfly larvae were examined 17 and $20 \mathrm{~d}$ after possible infection, but none of them proved to be infected. On Day 15, 1 freshly metamorphosed $B$. bombina and $2 T$. vulgaris tadpoles were examined; the frog was parasitized by $14 \mathrm{~A}$. crassus larvae, whereas the $T$. vulgaris tadpoles harboured 11 and 12 larvae. The nematode larvae $\left(\mathrm{L}_{3}\right)$ were unencapsulated, located in both host species in the body cavity, most frequently on the gut surface, and were 884 to $1292 \mu \mathrm{m}$ long and 27 to $41 \mu \mathrm{m}$ wide. The last $T$. vulgaris tadpole, examined $49 \mathrm{~d}$ PI, harboured altogether 3 motile, unencapsulated $A$. crassus larvae $\left(\mathrm{L}_{3}\right), 680$ to $843 \mu \mathrm{m}$ long and $27 \mu \mathrm{m}$ wide, 2 of them located in the body cavity and 1 under the skin of the host's leg.

\section{Expt 4}

Copepods Cyclops strenuus were infected with Anguillicola crassus in 27 large petri dishes in midOctober 1997. An examination of 4 copepods $14 \mathrm{~d}$ PI showed that all of them were infected, harbouring 1 to 3 A. crassus infective larvae $\left(\mathrm{L}_{3}\right)$. At that time, many copepods still survived in each petri dish. They were concentrated and, subsequently, those from 17 petri dishes were added to 1 petri dish $(20 \mathrm{~cm}$ in diameter) containing 6 rather large (about $2 \mathrm{~cm}$ long) alderfly larvae Sialis lutaria, whereas those from the remaining 10 petri dishes were transferred to another petri dish of the same size containing 10 isopods Asellus aquaticus, 10 dragonfly larvae Coenagrion puella, 1 larva of the caddisfly Oligotrichia striati, 2 large-sized, unidentified dipteran larvae (Diptera) and 3 unidentified larvae of aquatic beetles (Coleoptera). All copepods disappeared from both experimental petri dishes within a few days.

Two Sialis lutaria larvae were examined $17 \mathrm{~d}$ after possible infection and both harboured (4 and 39) living Anguillicola crassus $\mathrm{L}_{3}$ on their gut surface; the nematode larvae were coiled, some of them being encapsulated by a thin colourless membrane, and their body size was similar to that of larvae from copepods. Two other S. lutaria larvae were examined 41 and $69 \mathrm{~d}$ PI and were found to be infected by 6 and 44 living $A$. crassus larvae (Fig. 1A, B), respectively; the nematode larvae were again located on the gut surface, most of them encapsulated by a thin colourless membrane with irregularly scattered reddish-brown spots. The morphology and measurements of these larvae were similar to those of larvae from copepods. Two remaining $S$. lutaria larvae were used for the feeding experiment with eels.

The single Oligotrichia striati larva was examined $17 \mathrm{~d}$ PI and 31 motile Anguillicola crassus $\mathrm{L}_{3}$ were found in the body cavity of the middle and posterior parts of the abdomen. The larvae were mostly coiled, but none of them was encapsulated. Their size was similar to that of larvae from copepods.

Only 3 of the original 10 experimental dragonfly larvae Coenagrion puella survived; these were examined on Days 7, 17 and 41. Of them, only the larva examined $41 \mathrm{~d}$ PI was found to harbour Anguillicola crassus $\mathrm{L}_{3}\left(10 \mathrm{~L}_{3}\right.$ in the body cavity of the thorax and the abdomen); the nematode larvae, similar to those from copepods, were unencapsulated and freely moving. Isopods and other insect larvae proved to be uninfected.

\section{Expt 5}

To prove the ability of Anguillicola crassus larvae $\left(\mathrm{L}_{3}\right)$ from paratenic hosts to infect the definitive host, 2 Sialis 

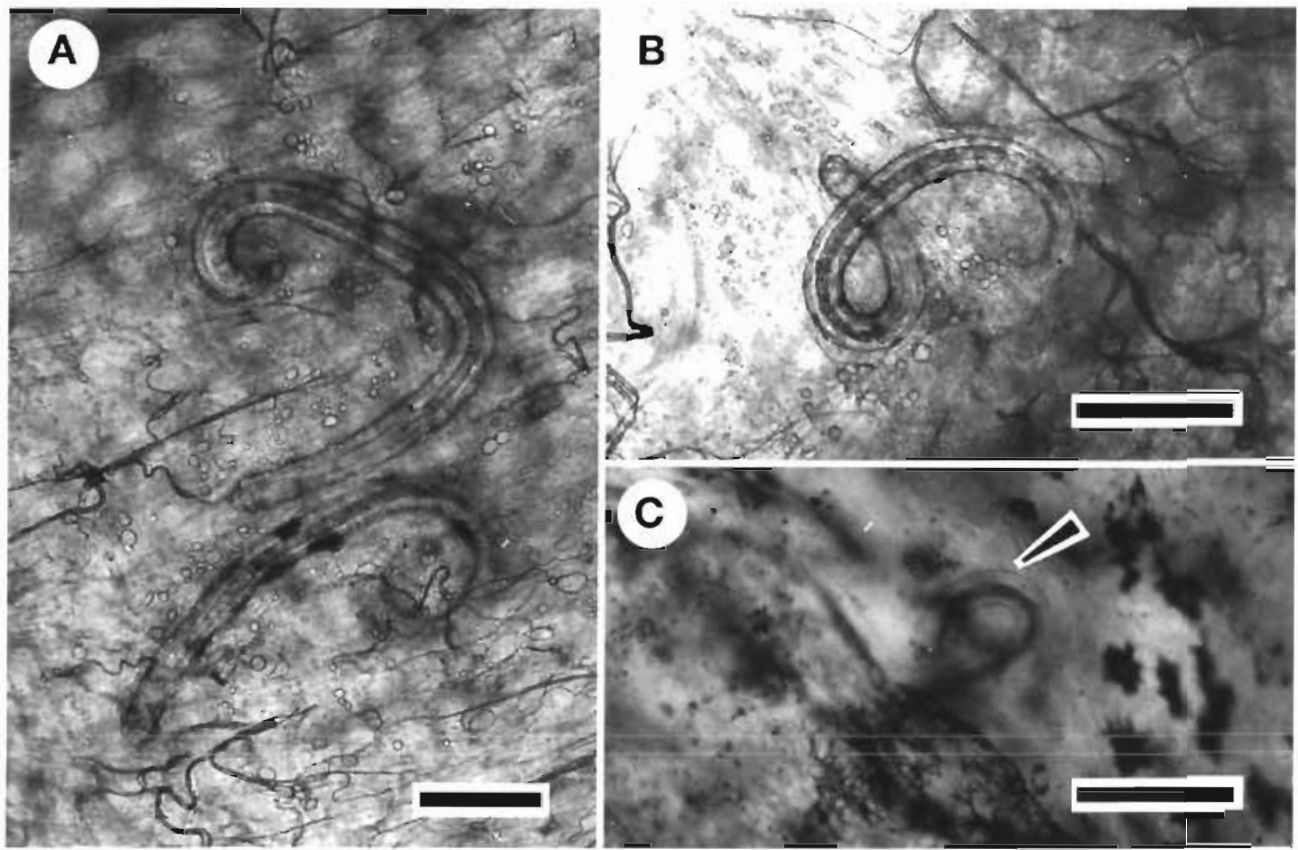

Fig. 1. Anguillicola crassus. Larvae from experimental paratenic hosts (fresh mounts). (A, B) Encapsulated third-stage larvae on gut surface of Sialis Iutaria $69 \mathrm{~d}$ after possible infection (PI). (C) Third-stage larva (arrow) in mesentery of Triturus vulgaris $49 \mathrm{~d} \mathrm{PI}$. Scale bars $=200 \mu \mathrm{m}$

lutaria larvae from Expt 4, presumed to harbour undetermined numbers of $A$. crassus third-stage larvae $69 \mathrm{~d}$ $\mathrm{Pl}$, were added to a small aquarium with 2 small Anguilla anguilla eels. Both $S$. lutaria larvae were immediately ingested by the larger eel specimen ( $20 \mathrm{~cm}$ long). The eels were examined $27 \mathrm{~d}$ later. The smaller specimen (17 cm long) proved to be uninfected, whereas the larger one was infected by a total of $77 \mathrm{~A}$. crassus: 74 third-and fourth-stage larvae at a different state of development inside the host's swimbladder wall and 3 juvenile adults (2 smaller whitish specimens and 1 larger, dark-coloured specimen) in the swimbladder lumen.

\section{DISCUSSION}

The results of this study (Table 1) show, for the first time, that not only various prey fishes and aquatic

Table 1. Survey of experiments with paratenic hosts of Anguillicola crassus

\begin{tabular}{|c|c|c|c|c|c|}
\hline $\begin{array}{l}\text { Animal species in } \\
\text { experiment }\end{array}$ & $\begin{array}{l}\text { No. of specimens } \\
\text { in experiment }\end{array}$ & $\begin{array}{l}\text { No. of specimens } \\
\text { infected }\end{array}$ & Intensity & Localization & $\begin{array}{l}\text { Examination of } \\
\text { animals (d PI) }\end{array}$ \\
\hline \multicolumn{6}{|l|}{$\begin{array}{l}\text { Invertebrates } \\
\text { Isopoda }\end{array}$} \\
\hline Asellus aquaticus & 10 & 0 & - & - & 69 \\
\hline $\begin{array}{l}\text { Megaloptera } \\
\text { Sialis lutaria }\end{array}$ & 6 & Probably all $6^{\mathrm{d}}$ & \multicolumn{3}{|c|}{ Megaloptera } \\
\hline \multicolumn{6}{|l|}{ Odonata } \\
\hline Coenagrion puella & 4 & 1 & 10 & Body cavity & $7,17,41$ \\
\hline Lestes sponsa & 1 & 0 & - & - & 7 \\
\hline Sympecma fusca & 3 & 0 & - & - & 17 \\
\hline Sympetrum sanguineum & 3 & 1 & 3 & Body cavity & 8 \\
\hline \multicolumn{6}{|l|}{ Trichoptera } \\
\hline Oligotrichia striata & 1 & 1 & 31 & Body cavity & 17 \\
\hline \multicolumn{6}{|l|}{ Amphibia } \\
\hline Triturus vulgaris & 4 & 3 & $3-12$ & $\begin{array}{l}\text { Body cavity, } \\
\text { liver, skin }\end{array}$ & $15,33,49$ \\
\hline Bombina bombina & 13 & 10 & $1-14$ & $\begin{array}{l}\text { Body cavity } \\
\text { beneath skin }\end{array}$ & $\begin{array}{l}5,12,14,16 . \\
19,29,33\end{array}$ \\
\hline
\end{tabular}


snails but also amphibians and aquatic insect larvae (Odonata, Trichoptera, Megaloptera) may serve as paratenic hosts to Anguillicola crassus, in which the nematode third-stage larvae can survive and keep their infectivity to the eel definitive host for at least 2 mo. This suggests that $A$. crassus may utilize a very wide range of paratenic hosts which, undoubtedly, play an important role in its transmission.

Eels Anguilla anguilla are generally regarded as being essentially benthic in habit, feeding mainly on zoobenthic organisms and, whilst showing great trophic opportunism, they consume a wide spectrum of bottom-living invertebrates; larger eels also consume various small, largely benthic fishes (Tesch 1977, Baruš \& Oliva 1995). However, Kennedy et al. (1992a) have shown, on the basis of their study of eel parasite communities, that eels of all sizes feed regularly upon planktonic copepods. But, in any case, it is clear that larger eels consume mostly benthic invertebrates such as arthropods and mollusks, which may probably represent an important source of Anguillicola crassus infection for them.

Unfortunately, at present no data exist on the occurrence of Anguillicola crassus larvae in naturally infected invertebrate paratenic hosts. However, the larvae of alderfly Sialis lutaria, for example, were reported by Moravec et al. (1997) as frequent paratenic hosts of 2 other fish helminths which utilize planktonic copepods and/or ostracods as obligate intermediate hosts: in the Jihlava River, Czech Republic, they found $13 \%$ of $S$. lutaria to be infected with larvae of the cestode Proteocephalus torulosus (Batsch, 1786) and 6\% with juveniles of the acanthocephalan Neoechinorhynchus rutili (Müller, 1780). In England, the prevalence of Proteocephalus sp. larvae in S. lutaria was found to range from 5 to $41 \%$ in different localities (Kennedy et al. 1992b), and in Scotland $N$. rutili juveniles were recorded from $7 \%$ of the same paratenic host species from Loch Monzievaird (Lassiere 1988). These relatively high percentages contrast to usually very low prevalences of helminth larvae in naturally infected copepod or ostracod intermediate hosts. It suggests that a concentration of helminth larvae occurs in these paratenic hosts due to the consumption of infected small motile intermediate hosts (copepods, ostracods). In addition, helminth larvae can survive in the paratenic host for a much longer period than in the copepod intermediate host, where the relatively short lifespan of these hosts (at most about 3 mol may be a limiting factor. The present experimental results confirm that A. crassus larvae can survive in S. lutaria and maintain their infectivity to the eel host for more than 2 mo, but it is highly probable that this period is much longer.

In some localities with still waters, such as lakes, pools or ponds, amphibian tadpoles, which actively feed on plankton, probably play a role in the transmission of Anguillicola crassus. It can be assumed that available tadpoles also become prey of larger eels in some localities. A record of the amphibian nematode Hedruris androphora Nitzch, 1821, a common parasite of newts, in Anguilla anguilla in Austria (Kritscher 1983) indicates that also some adult amphibians may also be occasionally swallowed by eels.

Acknowledgements. Our thanks are due to Mrs I. Husáková Institute of Parasitology, ASCR, for her excellent technical assistance and to Prof. E. Sedlák, Masaryk University in Brno, for the identification of the trichopteran larva. This paper was supported by grant no. 508/94/0284 from the Grant Agency of the Czech Republic.

\section{LITERATURE CITED}

Baruš V (1994) Eels' life is at stake. Rybáŕství 11:328-329 (in Czech)

Baruš V (1995) First record of Anguillicola crassus (Nematoda) in the Morava River drainage basin. Helminthologia (Bratisl) 32:89

Baruś V, Oliva $O$ (eds) Lampreys Petromyzontes and fishes Osteichthyes, Part 2. Fauna CR a SR 28. Academia, Praha (in Czech)

De Charleroy D, Grisez L, Thomas K, Belpaire C, Ollevier F (1990) The life cycle of Anguillicola crassus. Dis Aquat Org 8:77-84

Fries LT, Williams DJ, Johnson SK (1996) Occurrence of Anguillicola crassus, an exotic parasitic swim bladder nematode of eels, in the southeastern United States. Trans Am Fish Soc 125:794-797

Haenen OLM, van Banning P (1990) Detection of larvae of Anguillicola crassus (an eel swimbladder nematode) in freshwater fish species. Aquaculture 87:103-109

Johnson SK, Fries LT, Williams J, Huffman DG (1995) Presence of the swim bladder nematode, Anguillicola crassus, in Texas aquaculture. World Aquaculture 26:35-36

Kennedy CR, Nie P, Kaspers J, Paulisse J (1992a) Are eels (Anguilla anguilla L.) planktonic feeders? Evidence from parasite communities. J Fish Biol 41:567-580

Kennedy CR, Nie P, Rostron J (1992b) An insect, Sialis lutaria, as a host for larval Proteocephalus sp. J Helminthol 66: $7-16$

Kritscher E (1983) Die Fische des Neusiedler Sees und ihre Parasiten IV. Nematoda. Ann Naturhist Mus Wien Ser B, Bot Zool 84:123-126

Kuwahara A, Nimi A, Itagaki H (1974) Studies on a nematode parasite in the air bladder of the eel I. Description of Anguillicola crassa n. sp. (Philometridea, Anguillicolidae). Jpn J Parasitol 23:275-279

Lassiere OL (1988) Host-parasite relationships between larval Sialis lutaria (Megaloptera) and Neoechinorhynchus rutili (Acanthocephala). Parasitology 97:331-338

Molnár K, Székely Cs, Baska F (1991) Mass mortality of eel in Lake Balaton due to Anguillicola crassus infection. Bull Eur Assoc Fish Pathol 11:211-212

Moravec F (1996) Aquatic invertebrates (snails) as new paratenic hosts of Anguillicola crassus (Nematoda: Dracunculoidea) and the role of paratenic hosts in the life cycle of this parasite. Dis Aquat Org 27:237-239

Moravec F, Di Cave D, Orecchia P, Paggi P (1993) Studies on 
the development of Anguillicola crassus Kuwahara, Niimi et Itagaki, 1974 (Nematoda: Dracunculoidea) in the intermediate host. Folia Parasitol 40:39--48 and Erratum 40:160

Moravec F, Konecny R (1994) Some new data on the intermediate and paratenic hosts of the nematode Anguillicola crassus Kuwahara, Niimi et Itagaki, 1974 (Dracunculoidea), a swimbladder parasite of eels. Folia Parasitol 4.1. $65-70$

Moravec F, Konečný R, Baska F, Rydlo M, Scholz T, Molnár K, Schiemer F (1997) Endohelminth fauna of barbel, Barbus barbus (L.), under ecological conditions of the Danube basin in Central Europe. Academia, Praha

Moravec F, Taraschewski H (1988) Revision of the genus Anguillicola Yamaguti, 1935 (Nematoda: Anguillicolidae) of the swimbladder of eels, including descriptions of two new species, $A$. novaezelandiae sp. n. and $A$. papernai sp. n. Folia Parasitol 35:125-146

Ooi HK, Wang WS (1996) An epizootic of anguillicolosis in cultured American eels in Taiwan. J Aquat Anim Health 8:163-166

Pazooki J, Székely Cs (1994) Survey of the paratenic hosts of Anguillicola crassus in Lake Velence, Hungary. Acta Vet Hung 42:87-97

Petter AJ, Cassone J, Le Belle N (1990) Observations sur la biologie des premiers stades larvaires d'Anguillicola crassus, nématode parasite d'anguille. Ann Parasitol Hum

Editorial responsibility: Wolfgang Körting,

Hannover, Germany
Comp 65:28-31

Petter AJ, Fontaine YA, Le Belle N (1989) Étude du dévelopment larvaire de Anguillicola crassus (Dracunculoidea) chez un Cyclopidae de la région parisienne. Ann Parasitol Hum Comp 64:347-355

Reimer LW, Hildebrand A, Scharberth D, Walter U (1994) Anguillicola crassus in the Baltic Sea: field data supporting transmission in brackish waters. Dis Aquat Org 18: $77-79$

Székely Cs (1994) Paratenic hosts for the parasitic nematode Anguillicola crassus in Lake Balaton, Hungary. Dis Aquat Org 18:11-20

Székely Cs (1995) Dynamics of Anguillicola crassus (Nematoda: Dracunculoidea) larval infection in paratenic host fishes of Lake Balaton. Hungary. Acta Vet Hung 43: $401-422$

Tesch FW (1977) The eel: biology and management of anguillid eels. Chapman \& Hall Ltd, London

Thomas K, Ollevier F (1992) Paratenic hosts of the swimbladder nematode Anguillicola crassus. Dis Aquat Org 13: $165-174$

van Banning P, Haenen OLM (1990) Effects of the swimbladder nematode Anguillicola crassus in wild and farmed eel, Anguilla anguilla. In: Perkins FO, Cheng TC (eds) Pathology in marine science. Academic Press, New York, p $317-330$

Submitted: February 13, 1998; Accepted: August 10, 1998 Proofs received from author(s): October 9, 1998 